\title{
PERUBAHAN POLA PERILAKU SOSIAL-EKONOMI MASYARAKAT SUB-URBAN DENGAN MENGELOLA HOME INDUSTRY KERIPIK TEMPE DI KABUPATEN PONOROGO
}

\author{
Sudarmiani \\ MTh. Kuswariningsih \\ Dosen Prodi Pendidikan Ekonomi IKIP PGRI MADIUN
}

\begin{abstract}
Abstrak : Penelitan ini bertujuan menjelaskan dan menganalisis pola perilaku sosialekonomi masyarakat sub-urban dengan mengelola home industry untuk meningkatkan pendapatan keluarga Teknik pengumpulan data menggunakan (1) pengamatan dengan melakukan pemotretan (camera/visual), (2) wawancara terstruktur, (3) wawancara secara mendalam, dan (3) membuat life history. Hasil penelitian menunjukkan bahwa mulai tergesernya usaha sektor pertanian dengan berbagai sebab, menyebabkan masyarakat sub urban melakukan kegiatan non pertanian. Salah satu kegiatan non pertanian tersebut adalah dengan mengembangkan usaha industri rumah tangga pembuatan keripik tempe. Usaha pembuatan keripik tempe tersebut merupakan usaha keluarga, dengan omzet yang tidak besar hanya memerlukan modal relative kecil, berasal dari tabungan, pinjaman keluarga atau pinjam dari arisan. Pengelolaan usaha rumah tangga keripik tempe menggunakan sistem manajemen keluarga. Hal ini disebabkan adanya keterbatasan modal dan pola pemasaran yang tidak pasti (musiman), apabila mempekerjakan karyawan dengan memberikan gaji yang rutin mereka tidak mampu untuk menggaji.
\end{abstract}

Kata kunci : Home Industry Keripik Tempe, Masyarakat Sub-Urban, Pendapatan Keluarga

\section{PENDAHULUAN}

Kegiatan pertanian menurut pandangan Sajogyo, sebenarnya bukan lagi merupakan kegiatan yang menguntungkan secara ekonomis (Sajogyo, 1982). Hal itu disebabkan karena sebagaian besar lahan yang dikelola para petani sangat sempit atau kurang dari 0.50 hektar. Bahkan berdasarkan data BPS Kab. Ponorogo menyebutkan bahwa berdasarkan sensus Pertanian tahun 1993, keluarga petani di Ponorogo sebagaian besar hanya memiliki lahan di bawah 0,50 hektar. Iwan Kurtiawan (1997) mencermati menyusutnya lahan pertanian ini salah satunya disebabkab oleh alih fungsi lahan pertanian. Alih fungsi lahan pertanian ini sebagai konsekuensi dari (1) pertumbuhan kota, (2) faktor internal masyarakat petani, terjadi peningkatan jumlah rumah tangga pe- tani yang mengakibatkan makin sempitnya tanah yang diusahakan. Semakin besar perubahan luas lahan per rumah tangga pertanian pengguna lahan, semakin besar pengaruhnya terhadap penyusutan lahan, oleh Clifford Geertz (1981), proses ini disebut involusi pertanian. Terakhir, kebijaksanaan yang bias kota (lihat Hart, 1986).

Dari pengamatan awal dan mengikuti teori Everett S. Lee (1995) proses yang terjadi kemudian masyarakat bergeser dari sektor pertanian ke sektor non-pertanian, atau memasuki perkotaan, bila mengalami kegagalan dalam menyesuaikan dengan lingkungan sosial dan binaannya (Gardner, 1985). Artinya, keberhasilan ditentukan oleh kemampuan dalam menyesuaikan perubahan lingkungannya. Ketidakberhasilan masyarakat sub-urban akan mengakibatkan tingkat 
urbanisasi yang sangat tinggi di perkotaan. Dengan demikian wilayah sub-urban kemudian gagal menjadi penyangga kota. Karena keterbatasan daya tampungnya kota, maka yang terjadi meningkatnya pengangguran dan setengah pengangguran (Todaro dan Stilkind, 1991; McGee, 1991).

Pada tahun 1990-an usaha home industry ini pernah mengalami kehancuran dengan masalah kenaikan harga bahan kedelai. Kini, lebih dari satu dekade mereka mampu bangkit kembali, dan bahkan mengembangkan pangsa pasar sendiri di lingkungannya. Oleh karenanya, penelitian ini dilakukan dengan pendekatan kualitatif, dengan studi kasus untuk mencermati lebih dalam, mencoba menggali strategi adaptif dalam membangun usaha baru non pertanian, yaitu mengelola usaha home industry, termasuk perubahan pola perilaku sosialekonomi, hubungan antara pengelola dan pekerjanya, antara pengelola dan pemasok yang sebenarnya masih merupakan kerabatnya (satu desa). Survai digunakan untuk memperoleh gambaran secara lengkap dengan struktur sosial dan ekonomi masyarakat sub-urban yang telah bergeser.

Menyusutnya lahan pertanian yang dapat diusahakan oleh keluarga petani dan mahalnya biaya sarana produksi pertanian, menyebabkan kegiatan usaha pertanian secara ekonomis tidak lagi menguntungkan.Oleh karena itu banyak dari keluarga petani tersebut yang mencari terobosan untuk meningkatkan penghasilannya melalui kegiatan off farm. Kegiatan off farm banyak dilakukan oleh masyarakat sub-urban, karena realitasnya usaha off farm ternyata justru sangat kebal terhadap krisis ekonomi. Salah satu contohnya adalah dengan mengelola usaha home industry yang berupa usaha tempe kripik.

Usaha home industry sebagai usaha yang berbasis rumah tangga.selain dapat menyerap tenaga kerja, secara sosial ekonomi juga dapat membantu meningkatkan kesejahteraan terhadap bukan saja kepada pelaku namun juda pada masyarakat sekitarnya. Hal ini disebabkan karena dengan mengelola usaha home industry akan melibatkan masyarakat sekitar untuk proses produksinya dan pemasarannya. Meskipun usaha home industry itu termasuk usaha mikro yang tidak terjena pajak, pada kenyataannya juga dapat meningkatkan pendapatan asli daerah melalui kunjungan para wisatawan kota. Banyak dari wisatawan kota yang berbelanja oleh-oleh khas suatu daerah dengan beraneka macam pilihan.

Logika sederhana dari penelitian ini adalah apabila pemberdayaan masyarakat sub urban terus dikembangkan dan didukung secara penuh oleh pemerintah daerah, maka akan dapat membuka lapangan kerja baru yang akan dapat mengurai banyaknya pengangguran karena semakin sempitnya luas lahan pertanian yang dapat diusahakan.

Tumbuhnya industri kecil pedesaan sudah cermati Sajogyo (1978: 5) pada dasawarsa pertama program pembangunan lima tahunan semasa pemerintahan Suharto. Revolusi Hijau dengan pemanfaatan hasilhasil teknologi yang menghasilkan bibit unggul, pupuk dan pestisida, dan Revolusi Biru dengan teknologi pengolahan lahan, yaitu traktor, telah memperbesar kesenjangan pemilikan tanah di pedesaan yang sudah terjadi sejak abad ke 19 - kebijakan pemerintah kolonial waktu itu, mulai dari sewa tanah, tanam paksa hingga liberalisasi ekonomi telah mengakibatkan perbedaan pemilikan tanah dan terbentuknya kelompokkelompok atas dasar pemilikan tersebut. Catatan terakhir ini merupakan hasil penelitian DH Burger (1984), dan Agus Trilaksana (2002).

Disadari atau tidak, hal ini merupakan konsekuensi dari rencana pembangunan jangka panjang I dengan trickle down effect theory yang diterapkan. Pada pelita I, disiapkan tenaga-tenaga terdidik dalam bidang pertanian, baru pelita-pelita berikutnya untuk bidang industri, mulai dari yang mendukung pengolahan hasil pertanian hingga produk- 
produk lain. Di daerah pedesaan, akibat beralihnya sektor pertanian ke sektor nonpertanian, strategi yang digunakan adalah pembentukan kelompok usaha bersama (KUB), sentra-sentra industri kecil, koperasi industri kecil dan kerajinan, mendirikan percontohan usaha industri kecil dan memberikan paket ketrampilan dan bimbingan teknologi. Tidak itu saja, ditopang dari dunia perbankan, tambahan atau bantuan modal dapat diperoleh dengan mudah, yaitu dengan KUK (Kredit Usaha Kecil) (Kanwil Deperindag, 1996: 30), meski temuan membuktikan sebaliknya, kredit tersebut lebih dipakai untuk membeli barangbarang konsumtif, daripada kegiatan usaha produktif (Priyambodo dan Suyanto, 1991: 34-35).

Pemerintah Jawa Timur menyiapkan strategi baru, mulai tahun 1996 mengeluarkan program GKD (Gerakan Kembali ke Desa), diteruskan dengan program PP-GKD (Pengusaha Pelopor Gerakan Kembali ke Desa) (Zuhdi, 1998: 1-2). Apa yang diharapkan oleh pemerintah Jawa Timur sangat sederhana sekali, pertama bahwa tidak ada atau berkurangnya aliran tenaga kerja dari desa ke kota (urbanisasi) karena daerah pedesaan mampu menyediakan lapangan kerja. Dengan menjadikan desa sebagai sentra-sentra industri kecil, konsumen dari kota datang untuk membeli, selain produsen memasarkan produknya melalui jaringan distribusinya. Artinya, dengan produknya, desa menjadi daerah tujuan wisata (Marshus, 1995: 19-36).

Hal ini seiring dengan apa yang dikatakan oleh John Naisbitt dalam Indonesia-Swiss Forum on Culture Interanational Tourism di Yogyakarta pada tanggal 23 Agustus 1995 tentang pola ekonomi baru pada era kesejagatan (globalisasi). Ia menjelaskan bahwa pola ekonomi mendatang merupakan sistem besar, namun terjadi peralihan dari ekonomi atau usaha besar ke usaha kecil, perusahaan lokal dengan jumlah tenaga kerja yang tidak besar, namun kualitas harus lebih baik, paling tidak dengan menggunakan prinsip think globally act locally. Meskipun demikian, tenaga kerja itu harus menguasai teknologi informasi, komunikasi person to person menjadi strategi pemasaran.

Dengan demikian, ada 2 (dua) peluang yang diperoleh dari masyarakat desa. Pertama, masyarakat kota terdekat menjadi konsumen yang bertransaksi langsung dengan produsen karena didukung oleh transportasi. Hal ini menjadikan harga lebih murah dengan kualitas barang yang sama karena memangkas biaya distribusi. Kedua, dengan jaringan telekomunikasi, transaksi penjualan antara produsen dan konsumen yang berada di luar jangkauan transportasi, bahkan di luar negeri dapat dilakukan.

\section{METODE PENELITIAN}

Penelitian ini menggunakan cara pandang neo-positivistik, fenomena perubahan perilaku masyarakat desa (sub-urban) haruslah dipandang sebagai gejala yang unik. Di dalam kondisi yang serupa, dengan lokasi sebagai desa pinggiran kota, strategi adaptifnya tidak sama, seperti yang dikemukakan dalam tinjauan pustaka, ada desa yang anggota masyarakat berinteraksi dengan sektor ekonomi kota, tetapi sebaliknya kedekatan lokasi tersebut digunakan untuk membangun atau merubah sektor ekonomi pedesaannya dengan tetap melihat beberapa peluang atau kesempatan yang dapat di peroleh dari perkembangan ekonomi masyarakat kota. Hal tersebut misalnya terlihat di sejumlah desa di Kec. Balong, Kabupaten Ponorogo.

Pemahaman peneliti dari pemahaman subyek (understanding for understanding) tentang strategi dan perilaku sosial-ekonomi dalam memperoleh atau meningkatkan pendapatan keluarga diperoleh dengan menggunakan penelitian kualitatif. Jenis penelitian kualitatifnya adalah grounded research. Meskipun demikian, sebelumnya untuk memperoleh setting lapangan, khususnya 
tentang struktur sosial dan ekonomi masyarakat, dilakukan survai. Dari survai, nampak pola-pola umum struktur sosial dan ekonominya, yang kemudian dengan adanya berbagai macam peluang akan mengembangkan pola sosial dan ekonomi baru yang memungkinkan untuk meningkatkan kesejahteraan hidupnya.

Berkaitan dengan perkembangan industri kecil pedesaan, tepatnya pinggiran kota dan perubahan perilaku sosial ekonomi dengan mengelola home industry, khususnya di daerah Ponorogo dan sekitarnya, maka penelitian ini mengambil lokasi di wilayah Kabupaten Ponorogo, yaitu Kec. Balong, khususnya Desa Ngumpul, Desa Gundik dan Desa Nailan.Ketiga desa tersebut, tanpa harus menggunakan indikator yang jlimet dari Dinas Perindustrian, telah berhasil mengembangkan produknya, bahkan telah menjadi sektor utama dalam sistem mata pencaharian.

Berkaitan dengan rumusan masalah, penelitian ini menggunakan pendekatan kualitatif, maka peneliti berfungsi sebagai instrumen penelitian. Namun demikian, pedoman wawancara pun dibuat untuk memudahkan peneliti menerima asupan data dari masyarakat.

\section{HASIL DAN PEMBAHASAN}

\section{A. Pola Perilaku Sosial Ekonomi Masyarakat Sub-Urban}

Prof. Bintarto, 1984, Kota adalah sistem jaringan kehidupan manusia yang ditandai oleh strata sosial ekonomi yang heterogen serta corak materialistis. Menurut Peraturan Menteri Dalam Negeri Republik Indonesia No 4/1980 Kota adalah wadah yang memiliki batasan administratif wilayah seperti kotamadya dan kota administrasi. Perkembangan teknologi telah merubah masyarakat pinggiran kota atau sub urban menjadikan wilayah pinggiran kota berubah menjadi pusat-pusat kegiatan mandiri dengan berbagai fasilitas untuk mencukupi kebutuhan hidup sehari-hari, mulai dari Minimart,
ATM, Pasar, Sekolah, Warnet, dll.

Strategi dan Mekanisme Survival. Ketika pertanian sudah menjadi lahan perumahan atau bangunan yang lain, masyarakat buruh tani penggarap sawah di sekitar Kecamatan Balong tidak boleh berdiam terus. Karena mereka dan keluarganya harus tetap bertahan hidup. Untuk memenuhi kebutuhan sehari-hari, mereka mencukupinya dengan membuat tempe mentah dan keripik tempe untuk dijual ke pasar, tetangga, atau dititipkan di toko. Namun karena keterbatasan modal, usaha mereka seperti jamur di musim hujan, hidup segan mati tak mau.Karena kalau dihentikan usahanya mereka tidak dapat membiayai hidup dan keluarganya. Oleh karena itu, pemerintah misalnya telah menawarkan berbagai fasilitas bantuan berupa pinjaman dengan bunga rendah, pelatihan ataupun peralatan usaha untuk keripik tempe.

Dalam penelitian, secara mendalam tim menanyakan bagaimana usaha yang dilakukan untuk memenuhi kebutuhan hidupnya, siapa yang yang bekerja dan bagaimana ibu rumah tangga turut pula dalam aktivitas tersebut (pertanyaan wawancara). Pertanyaan itu disampaikan untuk mencermati strategi yang kemudian diterapkan dalam bentuk mekanisme survival keluarga miskin.

Ada berbagai jawaban yang diperoleh dari pertanyaan dalam angket . Inti dari jawaban para anggota keluarga yang mengusahakan home industry keripik tempe menyebutkan bahwa mereka mengerahkan seluruh anggota keluarganya untuk bekerja dalam rangka memenuhi kebutuhan. Tidak itu saja, mereka juga tidak jarang bekerja ganda.Artinya, mereka melakukan dua atau tiga pekerjaan sekaligus dalam satu waktu.Kalau tidak mampu bekerja, maka mereka baru mengharapkan dari anggota keluarga lainnya.

Arisan sebagai tabungan dan sumber dana alternatif. Bagi para keluarga pelaku IKM banyak cara untuk mencukupi kebutuhan hidupnya dan juga untuk membiayai kegiatan usahanya. Kenyataan dalam 
penelitian ini menunjukkan bahwa mereka sebenarnya juga memiliki strategi tabungan melalui arisan.Arisan memaksa mereka menyisakan uangnya. Tabel 6.2 menunjukkan ada dua organisasi lokal yang paling banyak diakses oleh responden untuk kegiatan penghipunan dana, yaitu arisan kampung dan keagamaan tingkat kampung, sedangkan manfaat terbesar yang bisa dirasakan oleh anggota organisasi lokal tersebut dari kegiatan penghimpunan dana yang dilakukan adalah untuk keperluan menanggulangi/ mengurangi dampak musibah dan untuk memberi bantuan dana guna mengadakan hajatan. Terkait dengan $56,12 \%$ responden yang bergabung dalam arisan kampung untuk keperluan menanggulangi musibah, maka kegiatan tersebut dapat diindikasikan sebagai suatu mekanisme survival yang mereka lakukan untuk mengurangi kerentanan terhadap goncangan faktor eksternal. Sebagai contoh, musibah sebagai bentuk kerentanan seseorang karena musibah sifatnya mendadak dan tidak bisa selalu diantisipasi atau dikendalikan, yang efeknya bisa membuat seseorang menjadi sengsara dan miskin karena menghancurkan potensi yang ada pada dirinya yaitu kesehatan dan produktifitas. Artinya di sini mereka menginvestasikan dan mendayagunakan modal sosial berupa kepercayaan dan kesadaran bersama untuk memobilisasi potensi sumber daya keuangan dan mengakumulasikannya pada organisasi lokal untuk meminimalisir potensi terjadinya kemiskinan di antara mereka.

Lebih dari itu, tabel 1. bisa diartikan bahwa respoden menggunakan kegiatan penghimpunan dana yang memanfaatkan momen hajatan dan musibah paling banyak ditemui pada organisasi lokal yaitu arisan kampung dan keagamaan tingkat kampung.

\section{Tabel 1 : Akses Ekonomi melalui Peng- himpunan Dana}

\begin{tabular}{|l|c|c|c|c|}
\hline Organisasi Lokal & Haj & Musi & Dana & Total \\
\hline $\begin{array}{l}\text { Keagamaan tingkat } \\
\text { kampung }\end{array}$ & 6 & 1 & 1 & 8 \\
\hline Keagamaan tingkat Desa & 1 & 2 & 0 & 3 \\
\hline Arisan keluarga & 3 & 2 & 0 & 5 \\
\hline $\begin{array}{l}\text { Arisan kerja, koperasi, } \\
\text { dll }\end{array}$ & 2 & 1 & 1 & 4 \\
\hline Arisan kampung & 6 & 3 & 1 & 10 \\
\hline Parpol & 0 & 0 & 0 & 0 \\
\hline Pendidikan & 0 & 0 & 0 & 0 \\
\hline Kesenian & 0 & 0 & 0 & 0 \\
\hline Lain-lain & 0 & 0 & 0 & 0 \\
\hline Total & 18 & 9 & 3 & 30 \\
\hline
\end{tabular}

Hal ini terlihat bahwa terdapat 6 orang responden pada organisasi lokal keagamaan tingkat kampung dan 5 orang responden pada organisasi arisan lokal tingkat kampung. Kegiatan penghimpunan dana ini sudah merupakan budaya dan tradisi sehingga dianggap wajar. Hal lain yang bisa digambarkan adalah bahwa peran organisasi lokal adalah sebagai sarana reproduksi budaya dan tradisi terkait nilai, norma, dan sanksi sosial, dan bisa kita lihat bahwa yang mempunyai pengaruh paling kuat bagi responden adalah organisasi lokal arisan tingkat kampung dan keagamaan tingkat kampung.

\section{Tabel 2: Penggunaan Dana Pinjaman}

\begin{tabular}{|l|c|c|c|c|c|}
\hline Organisasi Lokal & Haj & Kes & Modal & $\begin{array}{c}\text { Lain- } \\
\text { lain }\end{array}$ & Tot \\
\hline $\begin{array}{l}\text { 1. Keagamaan } \\
\text { tingkat kampong }\end{array}$ & 0 & 4 & 3 & 4 & 11 \\
\hline $\begin{array}{l}\text { 2. Keagamaan } \\
\text { tingkat Desa }\end{array}$ & 0 & 0 & 0 & 0 & 0 \\
\hline 3. Arisan keluarga & 0 & 1 & 1 & 0 & 2 \\
\hline $\begin{array}{l}\text { 4. Arisan kerja, } \\
\text { koperasi, dan } \\
\text { sejenisnya }\end{array}$ & 1 & 1 & 0 & 1 & 3 \\
\hline $\begin{array}{l}\text { 5. Arisan } \\
\text { kampung }\end{array}$ & 2 & 6 & 13 & 9 & 30 \\
\hline 6. Parpol & 0 & 0 & 0 & 0 & 0 \\
\hline 7. Pendidikan & 0 & 0 & 0 & 0 & 0 \\
\hline 8. Kesenian & 0 & 0 & 0 & 0 & 0 \\
\hline 9. Lain-lain & 0 & 0 & 0 & 0 & 0 \\
\hline Total & 3 & 12 & 17 & 14 & 46 \\
\hline
\end{tabular}


Pada tabel 2 ada pola yang sama seperti pada tabel 1 bahwa terdapat dua organisasi lokal yang paling banyak diakses oleh responden untuk kegiatan penghipunan dana, yaitu arisan kampung dan keagamaan tingkat kampung. Selanjutnya tabel tersebut juga menunjukkan untuk kepentingan apa dana tersebut digunakan. Dari tabel itu, bagaimana potensi sumber daya keuangan dimobilisasi dan diakumulasi pada organisasi lokal dengan menggunakan kepercayaan dan kesadaran bersama untuk meminimalisir potensi terjadinya kemiskinan di antara mereka. Hal yang serupa pada tabel 2. terkait pendayagunaan kepercayaan dan kesadaran bersama dan penggunaan dana dalam memobilisasi potensi sumber daya keuangan. Perbedaannya adalah kegiatan mobilisasi potensi sumber daya keuangan tidak hanya sekedar digunakan untuk meminimalisir potensi terjadinya kemiskinan di antara mereka (atau bisa dikatakan kepentingan kolektif). Selain itu, hal itu digunakan untuk meningkatkan kemakmuran pada kehidupan pribadi masing-masing responden. Hal ini terlihat bahwa $76,47 \%$ responden yang tergabungdalam organisasi lokal arisan kampung menggunakan dana untuk keperluan menunjang modal usaha.

\section{B. Pengelolaan Home Industry Keripik Tempe di Kabupaten Ponorogo \\ Masalah Permodalan. Dalam} menjalankan kegiatan usaha ekonomi apapun, modal merupakan masalah yang penting, karena tanpa modal usaha tidak akan dapat berkembang. Minimnya wirausahawan di negara kita salah satu kendalanya adalah masalah permodalan. Meskipun telah banyak kebijakan pemerintah untuk memberikan bantuan modal usaha bagi UMKM dengan skema bunga yang rendah, namun bagi usaha dalam skala yang kecil untuk memperoleh juga banyak hambatannya.Bagi pengusaha skala kecil masalah modal terkadang menjadi masalah yang cukup penting untuk mengembangkan usahanya.
Usaha industri rumah tangga pembuatan keripik tempe di Kecamatan Balong, dengan mengambil sampel di Desa Nailan, Desa Ngumpul, dan Desa Gundik berdasarkan data yang diperoleh menunjukkan bahwa kegiatan usaha tersebut mayoritas adalah usaha yang sudah cukup lama dilakukan, meskipun juga banyak diantara mereka yang merupakan usaha rintisan baru. Berdasarkan hasil wawancara dengan Sumini dan Anjar, warga Desa Nailan, usaha keripik tempe yang dilakukan adalah usaha turun temurun dengan modal patungan dari keluarga.

Masalah Manajemen. Pengelolaan usaha rumah tangga keripik tempe menggunakan sistem manajemen keluarga. Hal ini disebabkan adanya keterbatasan modal dan pola pemasaran yang tidak pasti (musiman), apabila mempekerjakan karyawan dengan memberikan gaji yang rutin mereka tidak mampu untuk menggaji. Dengan mempekerjakan keluarga sendiri jumlah karyawan bisa ditambah atau dikurangi sewaktu-waktu. Hal ini juga untuk memberikan tambahan penghasilan kepada keluarga (batih). Seperti hasil wawancara dengan Astuti (33 tahun), pedagang keripik tempe di pasar Balong, bahwa keripik tempe yang dibuat berasal dari bahan baku tempe yang dibuat sendiri. Sedangkan kedelai sudah mempunyai penjual kedeleai langganan yang mengantar ke rumah setiap hari. Keripik tempe yang dibuat sehari membutuhkan $5 \mathrm{~kg}$ kedelai kemudian dibuat tempe. Dalam pembuatannya dibantu oleh adik dan keponakan dengan memberi upah setiap hari.Apabila ada pesanan maka pekerfja ditambah dengan minta bantuan keluarga (batih) yang rumahnya berdekatan dengan rumahnya.

Pengelolaan manajemen dengan sistem kekeluargaan ini memiliki keuntungan dan kerugian. Keuntungannya, apabila produksi tidak pasti dapat sewaktu-waktu menambah atau mengurangi karyawan. Sedangkan kerugiannya, membuat pola produksi stagnan, tidak ngoyo, dan keuntungan yang tidak pasti. 
Proses Produksi. Pembuatan tempe keripik yang dilakukan oleh para wanita ibu rumah tangga yang menjadi responden dilakukan mulai sore hari. Kegiatan pada sore hari tersebut dilakukan mulai mempersiapkan kedelai yang akan dibuat tempe. Mereka mulai mempersiapkan dengan cara membersihkan kedelai dengan air dan kemudian merendamnya. Kemudian kedelai tersebut diberi ragi dan tepung kanji untuk merekatkan kedelai tersebut. Kemudian kedelai tersebut diratakan di suatu tempat tertentu (di ler) untuk diratakan agar tertata secara merata dan tipis. Setelah itu kemudian ditutup dengan daun pisang atau daun jati, dan setelah sehari maka tempe tersebut sudah jadi. Menurut mereka apabila kedelai yang telah diratakan tersebut ditutup dengan plastik, hasilnya tidak bagus. Setelah tempe tersebut jadi maka kemudian tempe tersebut dipotong-potong sesuai dengan ukuran yang telah ditentukan.

Untuk tenaga kerja selama proses pembuatan tempe kripek, bagi ibu-ibu yang setiap hari hanya membuat tempe dengan bahan kedelai kurang lebih 2 liter atau $4 \mathrm{~kg}$ mereka membuatnya sendiri hanya dibantu oleh suaminya atau anaknya. Mereka sudah bertahun-tahun hanya membuat dengan jumlah yang relative sedikit tersebut karena berkaitan dengan ketersediaan tenaga kerja, terutama sekali pada waktu menggoreng yang cukup banyak menyita waktu.

Ada beberapa yang membuat tempe kripek setiap hari habis 4 liter atau $8 \mathrm{~kg}$. Mereka dalam mengerjakannya dibantu dengan tenaga wanita tetangganya, meski tidak jarang juga minta izin apabila ada keperluan untuk bekerja dirumahnya sendiri. Menurutnya usaha tempe kripek yang paling sulit adalah pada ketersediaan tenaga kerja apabila mau dikembangkan sebagai industry rumah tangga yang besar.

Masalah Pemasaran. Pengelolaan industry rumah tangga keripik tempe menggunakan sistem pemasaran berdasarkan pesanan, gethok tular (dari mulut ke mulut), dititipkan ke toko-toko, atau penjualan langsung (punya warung sendiri atau dijual sendiri di pasar). Untuk usaha tempe kripik yang produksinya relatif banyak seperti yang dilakukan oleh Ibu Tatik yang tinggal di Desa Gundik, pemasaran dilakukan dengan cara diambil para pengecer yang setiap 2 hari sekali datang. Di samping diambil oleh para pengecer Ibu ini juga memasarkan di tokonya sendiri dan juga melayani pembeli yang datang untuk dijadikan oleh-oleh.

Dengan demikian menurut para responden, pemasaran tempe kripek tersebut dilakukan dengan cara bermacam-macam sesuai dengan apa yang telah mereka lakukan selama ini. Mayoritas mereka menjual tempe kripik dipasar tradisional sekitarnya, dititipkan ke warung-warung atau warung makan sekitarnya. Dalam satu kali produksi, dipasarkan langsung ke pasar atau dititipkan ke warung/toko langsung habis, sehingga keripik tempe yang dijual benar-benar baru dan tidak sampai tersisa.

\section{Home Industry dan pola interaksi sosial di masyarakat}

Kegiatan home industry pembuatan keripik tempe mayoritas dilakukan oleh para wanita. Meski demikian, hal tersebut mengakibatkan wanita tidak bisa serta merta meninggalkan sektor domestiknya. Keterlibatan wanita dalam pemenuhan kebutuhan ekonomi keluarga tersebut merupakan salah satu strategi keluarga miskin untuk beradaptasi terhadap perubahan kondisi ekonomi. Menurut Jeni Klugman (2002:62) kaum miskin akan beradaptasi dengan perubahan ekonomi sesuai dengan konteksnya, ada perbedaaan antara di wilayah pedesaaan dan perkotaan.

Ada kecenderungan yang kuat dari keluarga miskin untuk mengembangkan diversifikasi pekerjaaan. Namun demi-kian usaha diversifikasi pekerjaaan ini tidak diarahkan untuk memperkuat modal, namun hanya dalam kerangka untuk memenuhi kebutuhan hidup, seperti apa yang diungkapkan oleh Wiradi (1985:48) pada pedesaan 
Jawa. Bahkan menurut Pujdiwati Sajogyo (1985; 122) bahwa untuk memenuhi kebutuhan ekonomi wanita sebagai istri tidak tinggal diam, tidak saja memberikan saran, namun juga ikut bekerja untuk menambah penghasilan.

Kegiatan usaha keripik tempe tersebut telah menjadikan wanita lebih berperan dalam hal membantu ekonomi keluarga meski tidak meninggalkan tugas domestiknya. Lebih dari itu, wanita juga telah mempunyai partisipasi tidak saja dalam pengambilan keputusan dalam persoalan domestik, tetapi juga dalah hal persoalan ekonomi keluarga dan juga telah keluar memasuki lembagalembaga publik. Usaha pembuatan keripik tempe tersebut telah menjadikan wanita mempunyai peran ganda, yaitu sebagai ibu rumah tangga pekerjaan domestiknya dan membantu bekerja unutk mencari nafkah dengan usaha pembuatan keripik tempe. Peran ganda tersebut akan sangat menguntungkan bagi wanita, tatkala mereka harus berperan sebagai single parent dengan alasan-alasan tertentu.

Dengan kegiatan usaha tersebut mereka juga telah masuk ke ranah public melalui kegiatan di lembaga-lembaga sosial tingkat kampong. Mereka juga membangun relasi usaha secara sederhana dengan pedagang kedelai yang saling menguntungkan, membangun relasi dengan para pembeli dan juga para pemilik warung-warung makan di sekitar tempat tinggalnya.

\section{PENUTUP}

\section{Simpulan}

Dari hasil penelitian diketahui bahwa masyarakat sub urban di wilayah Ponorogo, dengan lokasi penelitian kecamatan Balong dan Kecamatan Jetis menjalani pekerjaan melalui home industry keripik tempe selain untuk membantu pendapatan suami dengan pekerjaan yang tidak menentu, tetapi juga meneruskan usaha orangtua yang sudah dijalani sejak lama.

Namun dalam perjalanannya mereka terkesan tetap berada pada jalur nyaman.
Artinya mereka membuat keripik tempe dari waktu ke waktu dengan jumlah yang sama dan pemasaran yang sama. Tidak ada antusias untuk meluaskan usahanya. Selain masalah permodalan, mereka juga menganggap bahwa usaha yang dilakukan bukan mata pencaharian utama.

Meskipun hanya dilakukan relative terbatas, namun usaha tempe keripik ini dapat membantu mencukupi kebutuhan ekonomi keluarga, karena secara kontinu mereka setiap hari akan memperoleh penghasilan dari usaha tersebut. Mereka tidak akan meninggalkan usaha pembuatan keripik tempe tersebut, karena pekerjaan dari sector pertanian juga tidak menentu, sehingga meskipun keuntungannya tidak besar. Mereka menganggapnya masih lumintu untuk menambah pemasukan ekonomi keluarga.

Usaha pembuatan keripik tempe ini modalnya tidak terlalu besar, karena hanya menghabiskan rata-rata 2 liter kedelai, namun untuk modal tenaga kerja sangat menyita waktu. Pemerintah tidak pernah membantu permodalan mereka, hanya pernah membantu memberi wajan penggorengan. Modal berasal dari keluarga atau pinjam pada organisasi social melalui arisan lokal. Pemasarannya dilakukan dengan menjual sendiri di pasar tradisional, dititipkan di warung-warung atau ada pengecer yang mengambilnya dan juga pembeli langsung yang datang ke rumah.

\section{Saran}

Kegiatan usaha keripik tempe tersebut telah menjadikan wanita lebih berperan dalam hal membantu ekonomi keluarga meski tidak meninggalkan tugas domestiknya. Lebih dari itu, wanita juga telah mempunyai partisipasi tidak saja dalam pengamibilan keputusan dalam persoalan domestic, tetapi juga dalam hal persoalan ekonomi keluarga dan juga telah keluar memasuki lembaga-lembaga publik. Usaha pembuatan keripik tempe tersebut telah menjadikan wanita mempunyai peran ganda, yaitu sebagai ibu rumah tangga pekerjaan 
domestiknya dan membantu bekerja untuk mencari nafkah dengan usaha pembuatan keripik tempe. Peran ganda tersebut akan sangat menguntungkan bagi wanita, tatkala mereka harus berperan sebagai single parent dengan alasan-alasan tertentu.

\section{DAFTAR PUSTAKA}

Agus Trilaksana. 2002. Penerapan Teknologi Pertanian dan Sistem Penyakapan Tanah di Kabupaten Ponorogo. Tesis S2, FIB Universitas Indonesia.

Bintarto. 1997. Pengantar Geografi Kota.LIP SPRING.Yogyakarta.

Burger, D.H. 1984. Desa Ngablak (Kabupaten Pati) pada tahun 18691929. Dalam Sediono M.P. Tjondronegoro dan Gunawan Wiradi (penyunting). Dua Abad Penguasaan Tanah. Pola Penguasaan Tanah Pertanian dari Masa ke Masa. Jakarta: Gramedia.

Kompas. 2001. Jakarta Riuh Rendah Belanja dan Keruwetan Ekonomi. 14 November. Hlm. 33

Strauss, Anselm., dan Juliet Corbin. 2003. Dasar-dasar Penelitian Kualitatif. Tatalangkah dan Teknik Teoritisasi Data. Diterjemahkan oleh Muhammad Shodiq dan Imam Muttaqien. Yogyakarta : Pustaka Pelajar.
Suparno, Imam Utomo. 1999. Rencana Strategi dan Kebijaksanaan Pembangunan Daerah Jawa Timur tahun 1999-2003. Dalam Anshari Thayeb. Jawa Timur Dalam Perspektif Negara dan Masyarakat. Surabaya : Yayasan Lubuk Hati.

Sajogyo. 1982. Bunga Rampai Perekonomian Desa, Yogjakarta : Universitas Gajah Mada.

Wignyosoebroto, Soetandyo, et. al. 1992. Perkembangan Keluarga-keluarga Kecil Sejahtera di Daerah Pedesaan Pasuruan Yang Tengah Mengalami Proses Industrialisasi. Suatu Studi Grounded tenang Kemandirian dan Keberdayaan Masyarakat. Laporan Penelitian. Surabaya : Ikatan Sosiologi Indonesia Cab. Surabaya dan BKKBN Prov. Jawa Timur.

Wiradi, Gunawan. 1985. Ketenagakerjaan dalam Struktur Agraris di Pedesaan Jawa. Dalam Peter Hagul (penyunting). Pembangunan Desa dan Lembaga Swadaya Masyarakat. Jakarta : Rajawali.

Yoeti, Oka A.1993. Pengantar Ilmu Pariwisata. Bandung: Angkasa. 